\title{
KOMUNIKASI PEMASARAN DINAS PARIWISATA LAMONGAN DALAM MENGEMBANGKAN INDONESIA ISLAMIC ART MUSEUM SEBAGAI WISATA RELIGI
}

\author{
Abdul Ghofur, Juariyah. \\ Program Studi Ilmu Komunikasi, Fakultas Fisipol, Universitas Muhammadiyah Jember \\ Jl. Karimata no. 49 Jember \\ juariyah@unmuhjember.ac.id
}

\begin{abstract}
This research is about Marketing Communication of religious tourism in Lamongan Regency, which is interesting to study, because Lamongan Regency is rich in various kinds of new tourism potential to be developed, one of which is the Indonesian Islamic Art Museum tour. However, the Department of Tourism and Culture has not been able to maximize the important role in the development of tourist attraction. So this research aims to know and describe marketing communication strategy and the obstacles faced by Tourism and Culture Department in developing Tourism in Lamongan regency, and also know how visitor response to tour Indonesian Islamic Art Museum.

This research is done the location of Tourism and Culture of the Lamongan Regency. The problem of this research is how the marketing communication strategy and the obstacle of Tourism and Culture Department develop tourism Indonesian Islamic Art Museum in the Lamongan regency and how the visitor response to tour Indonesian Islamic Art Museum. This research uses a qualitative descriptive qualitative paradigm method through various stages of preliminary observation, interview, and documentation related to the marketing communication strategy of the Tourism and Culture Department.

The results showed that the implementation of the marketing communication strategy of Tourism and Kebudayan Department in developing tourism Indonesian Islamic Art Museum by doing stages knowing the potential of tourism Indonesian Islamic Art Museum, planning, implementation, and evaluation. Then the obstacles found in the implementation of marketing communication strategy is the lack of funds, communicators, messages, and media. Then the response of visitors is satisfied with the facilities and infrastructure of tourist Indonesian Islamic Art Museum.
\end{abstract}

Keywords: Marketing Communication, Tourism and Culture Department.

\begin{abstract}
Abstrak
Penelitian ini tentang Komunikasi Pemasaran wisata religi di Kabupaten Lamongan, yang menarik untuk diteliti, karena Kabupaten Lamongan kaya akan berbagai macam potensi wisata yang baru untuk dikembangkan salah satunya adalah wisata Indonesian Islamic Art Museum. Namun, Dinas Pariwisata dan Kebudayaan belum mampu memaksimalkan peran penting dalam pengembangan objek wisata yang dimiliki. Sehingga penelitian ini bertujuan untuk mengetahui dan mendeskripsikan strategi komunikasi pemasaran dan kendala yang dihadapi Dinas Pariwisata dan Kebudayaan dalam mengembangkan Pariwisata di Kabupaten Lamongan, dan juga mengetahui bagaimana tanggapan pengunjung terhadap wisata Indonesian Islamic Art Museum.

Penelitian ini dilakukan lokasi Dinas Pariwisata dan Kebudayaan Kabupaten Lamongan. Adapun permasalahan adalah bagaimana strategi komunikasi pemasaran dan kendala
\end{abstract}


Dinas Pariwisata dan Kebudayaan dalam mengembangkan Pariwisata Indonesian Islamic Art Museumdi Kabupaten Lamongan dan bagaimana tanggapan pengunjung terhadap wisata Indonesian Islamic Art Museum. Penelitian ini menggunakan metode deskriptif kualitatif paradigma kualitatif melalui dengan berbagai tahapan yaitu observasi pendahuluan, wawancara dan dokumentasi yang berkaitan dengan strategi komunikasi pemasaran Dinas Pariwisata dan Kebudayaan.

Hasil penelitian menunjukkan bahwa penerapan strategi komunikasi pemasaran Dinas Pariwisata dan Kebudayaan dalam mengembangkan pariwisata Indonesian Islamic Art Museum dengan melakukan tahapan mengetahui potensi wisata Indonesian Islamic Art Museum, perencanaan, pelaksanaan dan evaluasi. Kemudian kendala yang ditemukan dalam pelaksanaan strategi komunikasi pemasaran adalah minimnya dana, komunikator, pesan, dan media. Kemudian tanggapan pengunjung adalah puas terhadap sarana dan prasarana wisata Indonesian Islamic Art Museum.

Kata Kunci: Komunikasi Pemasaran, Dinas Pariwisata dan Kebudayaan.

\section{Pendahuluan}

Pariwisata merupakan industri hiburan yang dibutuhkan oleh setiap manusia. Pekerjaan atau rutinitas seharihari yang monoton menyebabkan timbulnya suatu keadaan yang menjenuhkan. Karena itu, manusia memerlukan suatu kegiatan yang sifatnya menghibur untuk menghilangkan kejenuhan. Kegiatan ini membantu seseorang agar memiliki waktu luang yang dapat digunakan untuk sarana pemulihan kejernihan pikiran, agar terhindar dari tekanan sehari-hari yang menjenuhkan bahkan dapat menyebabkan gejala yang disebut stress. Kegiatan yang dapat dilakukan seseorang dalam mengisi waktu luang adalah dengan melakukan kegiatan plesir atau juga disebut kegiatan pariwisata. Berwisata pada dasarnya adalah kegiatan yang dibutuhkan oleh setiap individu untuk mendapatkan sesuatu yang diinginkan baik secara fisik maupun psikologis, dengan melakukan kegiatan yang menyenangkan dalam waktu senggangnya. Saat ini wisata alam merupakan wisata yang paling diminati oleh para wisatawan (Yoety, 1985:237238). Kabupaten Lamongan sebagai salah satu kota yang berada di Provinsi Jawa Timur memiliki ragam keunikan dan daya tarik potensi sumber daya yang cukup besar baik sumber daya alam maupun sumber daya budaya yang digemari oleh para wisatawan. Yang mana potensi sumber daya tersebut didukung dengan keadaan iklim tropis menjadi nilai plus bagi Kabupaten Lamongan dalam mengembangkan sektor pariwisata ataupun kebudayaan sehingga dapat dikenal oleh masyarakat luas. Hal tersebut dapat dijadikan pembangunan pariwisata sebagai salah satu alternatif bagi Pemerintah Kabupaten Lamongan untuk 
meningkatkan daya tarik wisatawan mengunjungi Kabupaten Lamongan.

Beberapa wisata alam maupun buatan sudah banyak dikembangkan di Kabupaten Lamongan ini. Seperti Wisata Bahari Lamongan (WBL) dan Maharani Zoo merupakan icon utama yang menjadi obyek wisata unggulan di Kabupaten Lamongan. Namun terdapat juga beberapa obyek wisata lain yang tidak kalah menariknya, salah satunya ialah Indonesian Islamic Art Museum, napak tilas perjalanan Islam di lamongan, Lamongan dikenal sebagai kota yang memiliki banyak potensi wisata salah satunya wisata religi, dengan banyaknya petilasan-petilasan peninggalan Wali Songo yang berada di Lamongan, seperti makam Sunan Sendang Duwur, makam Dewi Sekardadu dan Museum Sunan Drajat, sehingga sangat tepat jika di Kabupaten Lamongan ada museum islam. Indonesian Islamic Art Museum merupakan destinasi wisata yang memiliki potensi menjadi wisata andalan Kabupaten Lamongan seperti Wisata Bahari Lamongan dan Maharani Zoo yang menjadi icon utama Pariwisata, namun kurangnya promosi yang dilakukan oleh Dinas Pariwisata dan Kebudayaan yang dianggap masih belum optimal menyebabkan wisata ini kurang diketahui oleh masyarakat umum khususnya warga Lamongan sendiri, Peneliti akan mengkaji permasalahan strategi komunikasi pemasaran Disparbud Kabupaten Lamongan sehubungan dengan promosi/penyebaran informasi dalam mengembangkan potensi wisata Indonesian Islamic Art Museum terhadap wisatawan. Hal itu didasari dengan asumsi bahwa upaya promosi dan pengembangan serta pelestarian haruslah sesuai dengan sudut pandang dan kearifan lokal. Dari uraian latar belakang, peneliti tertarik untuk meneliti Strategi Komunikasi Pemasaran Dinas Pariwisata dan Kebudayaan.

\section{Rumusan Masalah}

Dari latar belakang di atas dapat dirumuskan permasalahan sebagai berikut: Bagaimana strategi komunikasi pemasaran Dinas Pariwisata dan Kebudayaan Kabupaten Lamongan dalam mengembangkan pariwisata Indonesian Islamic Art Museum?

Apa saja kendala yang dihadapi Dinas Pariwisata dan Kebudayaan Kabupaten Lamongan dalam mengembangkan pariwisata Indonesian Islamic Art Museum ?

Bagaimana tanggapan pengunjung terhadap wisata Indonesian Islamic Art Museum? 


\section{Tujuan Penelitian}

Berdasarkan uraian di atas, maka tujuan yang hendak dicapai dalam penelitian ini adalah sebagai berikut :

Mengetahui strategi komunikasi pemasaran Dinas Pariwisata dan Kebudayaan Kabupaten Lamongan dalam mengembangkan pariwisata Indonesian Islamic Art Museum.

Mengetahui faktor-faktor kendala yang dihadapi Dinas Pariwisata dan Kebudayaan Kabupaten Lamongan dalam mengembangkan pariwisata Indonesian Islamic Art Museum.

Mengetahui bagaimana tanggapan pengunjung terhadap wisata Indonesian Islamic Art Museum.

\section{Kerangka Pemikir}

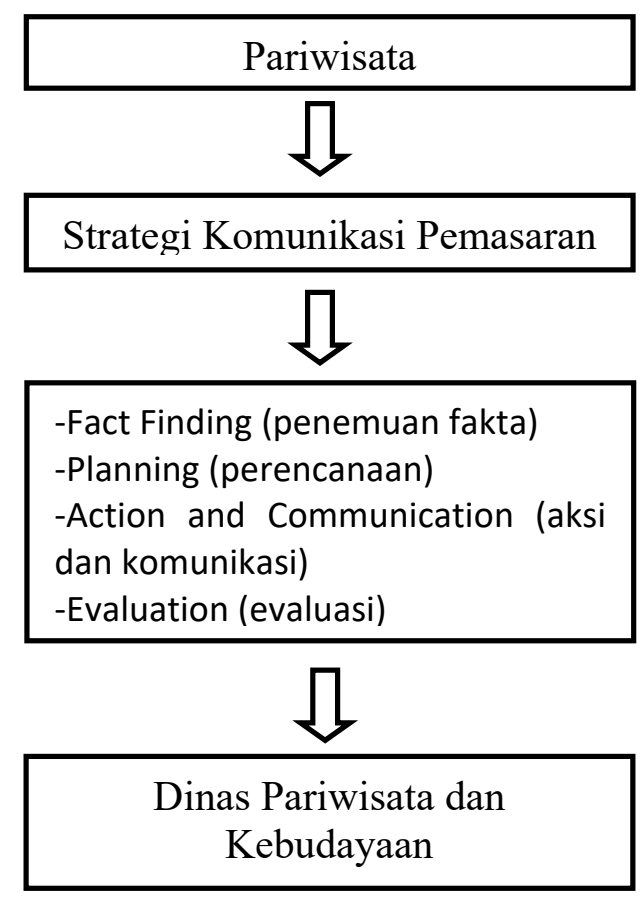

Gambar 1. Kerangka Pemikiran

\section{Metode Penelitian}

\section{Jenis Penelitian}

Jenis penelitian ini adalah penelitian kualitatif. Menurut Denzin dan Lincoln (dalam Moleong, 2012:5), menyatakan bahwa penelitian kualitatif adalah penelitian yang menggunakan latar alamiah, dengan maksud menafsirkan fenomena yang terjadi dan dilakukan dengan jalan menguraikan dan mendeskripsikan yang didasari dengan data dari lapangan. Penulis mengumpulkan data dari lapangan melalui staff Dinas Pariwisata dan Kebudayaan Kabupaten Lamongan (Disparbud) yang memiliki kaitan dengan masalah yang diangkat oleh penulis. Data yang dikumpulkan berupa kata-kata, angka-angka dan gambar.

Dalam hal ini, penulis melakukan penelitian dengan cara melakukan wawancara, mengamati dan mengumpulkan data, kemudian data yang diperoleh oleh penulis disusun, dikembangkan dan selanjutnya dikemukakan dengan seobjektif mungkin. Kemudian penulis menganalisa guna mendapatkan data-data yang diperlukan.

\section{Teknik Penentuan Sumber Data}

Teknis penentuan sumber data dalam penelitian ini menggunakan metode purposive sampling yang merupakan pengambilan sampel berdasarkan tujuan 
penelitian. Ciri khusus metode purposive sampling ialah jumlah subjek yang akan diteliti ditetapkan terlebih dahulu, barulah peneliti melaksanakannya. Informan yang tidak sesuai dengan kriteria populasi tidak dapat dijadikan sampel. Dalam teknik ini, siapa yang akan diambil sebagai informan diserahkan pada pertimbangan penelitian sesuai dengan maksud dan tujuan peneliti. Dengan kata lain, peneliti dapat menggunakan data berdasarkan sifat-sifat yang dianggap mewakili terhadap penelitian ini.

Pemilihan informan didasarkan pada kriteria dengan urutan sebagai berikut:

1). Kasubag Dinas Pariwisata dan Kebudayaan.

2). Aparatur Sipil Negara (ASN) yang ditunjuk oleh Dinas Pariwisata dan Kebudayaan Kabupaten Lamongan sebagai informan yang sudah bekerja minimal selama 1 tahun.

\section{Hasil Penelitian dan Pembahasan Penelitian}

Berdasarkan salah satu penetapan pencapaian kinerja Dinas Pariwisata dan Kebudayaan Kabupaten Lamongan khususnya di bidang pariwisata, yaitu meningkatnya jumlah kunjungan wisata. Sasaran ini dicapai melalui beberapa program, sebagai berikut: (Laporan Akuntabilitas Instansi Pemerintah Dinas
Pariwisata dan Kebudayaan Kabupaten Lamongan, 2018). Mengenai Strategi Komunikasi Pemasaran Dinas Pariwisata dan Kebudayaan Kabupaten Lamongan.

Berdasarkan hasil dari wawancara yang dilakukan oleh peneliti di Menwa Unmuh Jember hasilnya sebagai berikut :

\section{Pembahasan}

\section{1). Potensi daya tarik wisata}

Dinas Pariwisata dan Kebudayaan bekerjasama dengan pihak terkait dalam menjaring informasi terkait obyek pariwisata yang akan dipromosikan terhadap potensi wisata Indonesian Islamic Art Museum. seperti yang telah disampaikan oleh Arif Teguh Irawan sebagai Staf bagian Pengembangan.

yaitu: Disparbud perlu melakukan penggalian informasi terkait keunggulan wisata yang akan dikembangkan, secara garis besar kami melihat potensi yang dimiliki oleh Indonesian Islamic Art Museum sebagai salah satu wisata yang memiliki potensi bagus untuk dikembangkan. (Wawancara : senin, 30 April 2018).

seperti yang disampaikan oleh Diana Dewi Iswandari sebagai Kepala Seksi Promosi Informasi dan Pemasaran yang mengatakan sebagai

berikut: Sarana dan prasarana yang ditunjang dengan ruangan yang nyaman dan 
ber AC dan juga ada Tour Guide yang melayani para pengunjung sehingga pengunjung merasa nyaman ketika melakukan kegiatan di dalam area wisata Indonesian Islamic Art Museum". (Wawancara: Rabu, 02 mei 2018).

Sebagai salah satu wisata yang dikelola oleh swasta tentunya kerjasama dalam membangun sebuah hubungan sangatlah penting demi menjaga kreadibilitas dalam bekerja dan menjalankan profesi masing-masing dari managemen pengelolaan organisasi yang telah dibangun, adapun menurut Muntianah sebagai Kepala Seksi Usaha Ekonomi Kreatif, mengatakan,

Yaitu: Yang menjadi daya tarik Disparbud dalam mengembangkan wisata Indonesian Islamic Art Museum adalah bukan hanya karena memang sarana dan prasarananya yang baik akan tetapi juga sikap kooperatif dari manager wisata Indonesian Islamic Art Museum yang selalu aktif dalam menjalin hubungan dengan pihak Dinas Pariwisata. (Wawancara : jumat, 04 Mei 2018).

Dengan mengusung konsep baru dengan inovasi-inovasi dan juga terobosan dalam bidang pariwisata menunjukkan sikap konsisten yang dilakukan oleh pengelola dan tentunya juga dengan Dinas Pariwisata dan Kebudayaan. sebagaimana yang telah disampaikan oleh Sukadi sebagai Kepala Bidang Pemasaran, menyebutkan bahwa: Ini adalah museum Islam pertama di Indonesia yang hadir dengan konsep yang lebih modern dan berbeda dengan museum-museum pada umumnya. Sehingga ini menjadi sesuatu yang menarik untuk kita promosikan,Kita bisa mendownload aplikasi Augmented Reality (AR) Indonesian Islamic Art Museum di playstore. (Wawancara : senin, 07 Mei 2018).

\section{2). Perencanaan}

Sebagai bentuk dalam proses perencanaan pada dasarnya berpengaruh pada proses keberhasilan suatu strategi komunikasi pemasaran yang dilakukan oleh Disparbud. Dikarenakan suatu perencanaan sebagai langkah awal untuk mencapai tujuan yang terarah dan jelas sehingga secara keseluruhan komponen dalam suatu instansi mengetahui secara baik tujuan yang akan dicapai. seperti yang telah disampaikan oleh Arif Teguh Irawan sebagai Staf Bagian Pengembangan, yaitu: Dalam melakukan perencanaan yang maksimal Disparbud menjalin kerjasama dengan sekolah-sekolah dengan cara menyebar undangan khususnya dalam mempromosikan wisata Indonesian Islamic Art Museum. (Wawancara : senin, 30 April 2018). 
Tentunya untuk membuat inovasi yang baru sehingga menjadi suatu yang menjadi ciri khas dari sebuah tempat wisasta tentunya membutuhkan pemikiran yang kreatif, sebagaimana yang telah disebutkan oleh Diana Dewi Iswandari sebagai Kepala Seksi Promosi Informasi dan Pemasaran, yaitu: Disparbud menjalin kerjasama dengan pihak terkait untuk membuat aplikasi android yang bisa di download di Google Play Store secara mudah oleh semua orang, kemudian membuat program kelompok sadar wisata (Pokdarwis) yang melibatkan masyarakat setempat, kemudian diberikan pelatihan oleh Disparbud. (Wawancara: Rabu, 02 mei 2018).

Di dalam melakukan upaya promosi tentunya melalui beberapa tahapan salah satunya melalui media-media yang sekarang ini mudah untuk diakses oleh kalangan masyarakat secara luas, seperti yang telah disampaikan oleh Muntianah sebagai Kepala Seksi Usaha Ekonomi Kreatif sebagai berikut,

Yaitu: Promosi wisata melalui Media Sosial seperti Facebook dan Instagram ada juga website yang bisa diakses. Inovasi seperti ini baru dilakukan sekarang dan sebelumnya belum ada inovasi sedemikian rupa. Kelebihan inovasi seperti ini dinilai lebih efektif, karena secara otomatis dapat diakses oleh masyarakat. (Wawancara : jumat, $04 \mathrm{Mei}$ 2018).

Dalam mengembangkan sektor pariwisata tentunya ada beberapa eventtahunan yang di ikuti oleh Disparbud sebagai sarana untuk memperkenalkan berbagai macam potensi pariwisata, seperti yang telah disampaikan oleh Sukadi Kepala Bidang Pemasaran,

Yaitu: Disparbud berencana mengikuti eventMojopahit Trafel Fair (MTF) yang diselenggarakan di Grand City Surabaya dan nanti Indonesian Islamic Art Museum sebagai salah satu pariwisata yang diikut sertakan dalam event ini nanti. (Wawancara : senin, 07 Mei 2018).

\section{3). Pelaksanaan}

Pelaksanaan sendiri adalah sebagai wujud dari perencanaan yang sebelumnya telah dibuat. Indikator dari keberhasilan suatu pelaksanaan bisa dilihat dari seberapa baik perencanaan tersebut. Keberhasilan pelaksanaan juga akan berjalan dengan baik apabila ditunjang dengan kerjasama tim dan antar instansi yang terkait maupun masyarakat dalam pengembangan pariwisata daerah. sebagaimana yang telah disampaikan oleh Arif Teguh Irawan sebagai Staf Bagian Pengembangan yang menyatakan sebagai berikut, 
Yaitu: Salah satunya melakukan kerja sama dengan sekolah-sekolah yang disusun seperti kunjungan dan nanti akan diadakan berbagai macam kegiatan di dalam wisata Indonesian Islamic Art Museum, seperti menggambar, gamegame seru dan lain sebagainya. (Wawancara : senin, 30 April 2018).

Sebagai bentuk pelaksanaan strategi komunikasi pemasaran, Disparbud juga telah bekerjasama dengan pihak terkait untuk menyediakan aplikasi yang berbasis Android yaitu Aplikasi Lamongan tourism, Seperti yang telah disampaikan oleh Diana Dewi Iswandari sebagai Kepala Seksi Promosi Informasi dan Pemasaran yang menyebutkan sebagai berikut, Yaitu: Selain itu kami juga bekerja sama dengan pihak pengelola Wisata Bahari Lamongan (WBL) dimana kita memasukkan pilihan paket tiket, sehingga bisa langsung diketahui oleh wisatawan yang sedang berkunjung di Wisata bahari Lamongan. (Wawancara: Rabu, 02 mei 2018).

Dalam pelaksanaan tentunya harus sesuai dengan strategi dan penyusunan perencanaan sebelumnya, sebagaimana yang telah disampikan oleh Muntianah sebagai Kepala Seksi Usaha Ekonomi Kreatif,
Yaitu:strategi komunikasi pemasaran yang lain adalah dalam skala formal mengikuti event Mojopahit Travel Fair yang diselenggarakan di Grand City Surabaya. (Wawancara : jumat, $04 \mathrm{Mei}$ 2018).

Sebagai sarana komunikasi pemasaran adalah ketika bertemu dengan tetangga, saudara, teman dan lain sebagainya dengan cara memberikan suatu gambaran terhadap konsep pariwisata yang sedang dikembangkan oleh Disparbud tentang wisata Indonesian Islamic Art Museum, sebagaimana yang telah disampaikan oleh Sukadi selaku sebagai Kepala Bidang Pemasaran yang mengatakan sebgai berikut,

Yaitu: Dalam skala non formal kami mempromosikan melaui media sosial seperti Facebook dan Instagram, untuk saat ini baru itu yang bisa kami lakukan. (Wawancara : senin, 07 Mei 2018).

\section{4). Evaluasi}

Evaluasi adalah suatu usaha untuk mengukur dan sumber nilai secara objektif dari pencapaian hasil-hasil yang direncanakan sebelumnya, dimana hasil evaluasi tersebut dimaksudkan menjadi umpan balik untuk perencanaan yang akan dilakukan di depan. Sebagaimana yang telah disampaikan oleh Arief Soepriyatno selaku Kasubag mengatakan demikian, 
Yaitu: Selama ini bentuk evaluasi yang kami lakukan adalah dengan bentuk laporan pertanggungjawaban dari setiap proses pelaksanaan kegiatan yang dilaporkan setiap satu bulan sekali dalam rapat. (Wawancara : senin, 30 April 2018). Dalam wawancara yang telah peneliti lakukan, tidak semua bisa menjelaskan tentang evaluasi hanya orang yang bersangkutan saja, sehingga data yang diperoleh hanya sebatas ini.

\section{Kendala Disparbud}

\section{1). Minimnya Alokasi Dana}

Pada tahapan ini Disparbud melakukan evaluasi terhadap hasil pencapaian strategi komunikasi pemasaran yang telah dilaksanakan. Dari pencapaian suatu pelaksanaan terdapat beberapa faktor yang menjadi penghambat dalam proses pelaksanaan kegiatan. seperti yang telah dikemukakan oleh Arif Teguh Irawan selaku sebagai Staf Bagian Pengembangan yang menyatakan sebagai berikut,

Yaitu: Dalam proses pelaksanaan kegiatan strategi komunikasi pemasaran, kita kesulitan dalam melakukan kegiatan karena terkendala dana kami yang minimal. (Wawancara : senin, 30 April 2018).

\section{2). Kurangnya SDM}

Tentunya dalam sebuah organisasi terdapat beberapa tugas pokok dari setiap pegawai, terkait dengan segala bentuk upaya yang akan dilakukan dalam etos kerja, dengan kurangnya kredibilitas dari pegawai Disparbud menjadi salah satu kendala yang sekian lama telah dialami oleh Disparbud, sebagaimana yang telah disampaikan oleh Diana Dewi Iswandari selaku sebagai Kepala Seksi Promosi Informasi dan Pemasaran yang menyatakan kendala yang dialami,

Yaitu: Faktor penghambat lainya adalah kurangnya SDM dalam hal ini teknisi yang berkaitan dengan Teknologi dan Informasi yang bertugas untuk mengupdate perkembangan apa saja yang telah dilaksanakan oleh Disparbud. (Wawancara: Rabu, 02 mei 2018).

\section{3). Dikelola Oleh Swasta}

Kerjasama yang dijalin dengan baik dapat dilihat dari komunikasi yang efektif dilakukan secara keseluruhan, bisa diartikan bahwa hubungan yang dijalin baik, salah satu yang menjadi kendala dalam kegiatan komunikasi pemasaran adalah Indonesian Islamic Art Museum sendiri tidak secara penuh dikelola oleh Disparbud melainkan dikelola oleh swasta sehingga tidak bisa berkontribusi penuh hanya sekedar memberi masukan dan 
arahan kepada pihak pengelola, seperti yang telah dikemukakan oleh Muntianah selaku sebagai Kepala Seksi Usaha Ekonomi Kreatif yang mengatakan seperti demikian,

Yaitu: Karena dikelola oleh swasta, kita tidak bisa berkontribusi penuh terhadap proses promosi wisata, yang bisa kami lakukan hanya sebatas memberi masukan. (Wawancara : jumat, 04 Mei 2018).

\section{4). Komunikasi dalam internal}

\section{disparbud kurang harmonis}

Tidak dapat dipungkiri dalam sebuah organisasi tentunya terdapat berbagai perselisihan-perselisihan pendapat antara satu dan lainnya namun jika hal tersebut tidak bisa dikesampingkan akan menimbulkan tidak profesionalitas dalam bekerja, karena semua kegiatan tentunya melibatkan pegawai-pegawai yang berkaitan dengan kegiatan tersebut, namun sering kali karena keegoisan dari masingmasing individu menjadi penghambat dalam proses pelaksanaan kegiatan promosi yang dilakukan, sebagaimana yang telah dikemukakan oleh Sukadi selaku sebagai Kepala Bidang Pemasaran, yang menyatakan,

Yaitu : Dalam internal Disparbud kurang harmonis dalam menjalin hubungan kerja sama yang baik, sehingga menimbulkan suatu keadaan yang kurang kondusif. (Wawancara : senin, 07 Mei 2018).

\section{Tanggapan Pengunjung}

\section{1). Sarana dan Prasarana}

Tentunya dalam membangun sebuah obyek pariwisata untuk memperhatikan fasilitas yang menunjang kepentingan pengunjung sehingga ketika melakukan kegiatan pariwisata merasa nyaman, seperti yang dikemukakan oleh salah seorang pengunjung Budi dari Ponorogo yang mengatakan : Saya sebagai pengunjung merasa takjub melihat keindahan di dalam wisata Indonesia Islamic Art Museum, sarana dan prasarananya bagus dan dan nyaman.

Indikator keberhasilan dalam pengelolaan wisata tentunya bisa dilihat dari tingkat kepuasan pengunjung setelah berwisata pada suatu tempat, termasuk dalam menambah fasilitas-fasilitas baru, seperti yang telah dikemukakan oleh Susi dari Gresik,

Yaitu: Sarana dan prasarana di wisata Indonesia Islamic Art Museum menurut saya bagus, mungkin apabila ditambahkan keterangan-keterangan yang lebih lengkap mungkin akan lebih memudahkan pengunjung.

Untuk menambah nilai edukasi terhadap perjalanan perkembangan Islam runtut mulai dari awal hingga 
perkembangan sampai saat ini, termasuk menaruh ornamen-ornamen peninggalan Islam Nusantara, sebagaimana yang telah diungkapkan oleh Sukari dari Jogja yang mengatakan,

Bahwa: Tempat yang nyaman dan ornament-ornamen ciri khas budaya islam menarik untuk di lihat.

Tata letak sebuah tempat wisata tentunya mendukung dalam menarik minat terhadap kunjungan wisatawan baik lokal maupun mancanegara, namun hal ini sulit untuk diwujudkan terkait kendala lahan yang kurang memadai, seperti yang disampaikan oleh Naura dari Lamongan, yang mengatakan sebagai

Berikut: Jika tempatnya lebih diperluas sehingga lebih banyak lagi koleksi-koleksi sejarah peninggalan islam yang bisa ditaruh di museum ini.

Ditunjang dengan sarana dan prasarana yang baik dan mencukupi, mungkin akan lebih baik lagi, kemudian ditunjang oleh teknologi yang modern dengan teknologi Aplikasi Augmented Reality, , seperti yang telah dikemukakan oleh Abdul Muin dari Gresik yang mengatakan,

bahwa: Dengan menggunakan Aplikasi ini memudahkan untuk berfoto dengan konsep yang unik.
Prioritas utama dalam mengelola tempat wisata tentunya harus didukung dengan fasilitas yang memadai, seperti halnya toilet yang bersih, ruangan ber AC, seperti yang telah diungkapkan oleh Silvi Titasari dari Gresik, mengatakan seperti demikian,

Bahwa: menurut saya ini sangat bagus tentunya dalam melayani pengunjung.

Bukan hanya fasilitas-fasilitas umum yang didapatkan, namun juga mendapatkan fasilitas untuk mengabadikan momen untuk berfoto dengan tema yang lebih unik yang bisa dilakukan dengan keluarga, seperti yang diungkapkan oleh Rendra dari tuban, yang mengatakan sebagai berikut, Yaitu: Banyak spot foto yang bisa digunakan untuk berfoto mengabadikan momen bersama keluarga dengan mendownload Aplikasi yang disediakan di Play Store.

Salah satu daya tarik dari wisata ini bukan hanya beberapa fasilitas yang bisa dinikmati, akan tetapi juga totalitas kerja yang baik dengan pelayanan yang sopan dan ramah menjadikan pengunjung merasa nyaman, seperti yang disampaikan oleh Yudistira dari Sidoarjo yang mengatakan, Bahwa: pelayanannya juga sangat ramah terhadap pengunjung sehingga saya 
merasa nyaman ketika berkunjung di wisata ini.

Jika dibandingkan dengan harga tiket dan fasilitas yang didapatkan oleh pengunjung ini sangat Value Money sekali, seperti yang diungkapkan oleh Arif dari Lamongan, mengatakan,

bahwa: Dengan harga tiket yang diberikan menurut saya dari apa yang didapatkan didalam wisata ini sangat Value Money.

Dari wawancara yang telah dilakukan oleh peneliti mengenai tanggapan pengunjung terhadap sarana dan prasarana yang ada di wisata Indonesia Islamic Art Museum, menunjukkan bahwa mayoritas pengunjung menilai sarana dan prasarana baik, seperti ruangan ber $A C$, menggunakan teknologi modern, toiletnya bersih dan mencukupi, kemudian ditunjang adanya tour guide nya yang memandu wisatawan dalam menjelajahi berbagai zona yang ada di Indonesia Islamic Art Museum.

\section{2). Pengunjung Mengetahui Informasi}

\section{Tempat Wisata}

Dalam melakukan suatu promosi pariwisata tentunya melalui berbagai macam media yang digunakan, seperti melalui surat kabar, media sosial, pamphlet, baliho, termasuk juga melalui kerjasama yang dilakukan oleh pengelola wisata, seperti yang diungkapkan oleh Budi dari Ponorogo, mengatakan, Bahwa: Saya tadi awalnya berkunjung ke Wisata Bahari Lamongan (WBL) kemudian saya di beritahu oleh penjaga loket pembelian tiket bahwa ada wisata baru yang ada di sebelahnya WBL.

Dengan menjalin komunikasi yang baik dapat memberikan suatu informasi yang dibutuhkan maupun yang tidak dibutuhkan, salah satunya selalu menjalin komunikasi yang baik dengan keluarga, saudara, dan juga tetangga, seperti hanya yang disampaikan oleh Susi dari Gresik, mengatakan,

Bahwa: Informasi mengenai adanya wisata ini adalah dari tetangga saya yang sebelumnya pernah berkunjung kesini.

Beberapa media perantara yang dapat digunakan sebagai sarana untuk mempromosikan pariwisata salah satunya melalui baliho atau billboard adalah bentuk media promosi di jalan yang lebih besar dari spanduk, Sebagaimana yang diungkapkan oleh Sukari dari Jogja yang mengatakan

Berikut: Saya tidak sengaja melihat baliho yang ada didepan pintu masuk Wisata Bahari Lamongan tentang wisata ini.

Penyampaian pesan melalui media dari face to face mempermudah dalam proses penyampaian pesan, seringkali cara 
ini digunakan dalam strategi promosi pariwisata, seperti yang diungkapkan oleh Naura dari Lamongan, mengatakan,

Bahwa: Mengetahui informasi akan adanya wisata ini adalah seorang tetangga saya pernah berwisata disini.

Sangat jelas sekali jika promosi melalui face to face lebih mudah menyampaikan pesan langsung kepada komunikan, karena hambatan pesan yang disampaikan minim. Termasuk melalu baliho,seperti yang di ungkapkan oleh Abdul Muin dari Gresik, mengatakan

Bahwa: Zoo saya melihat baliho besar yang ada didepan jalan tentang wisata Indonesian Islamic Art Museum ini.

Maraknya media internet yang terus mengembangkan eksistensinya, membuat berbagai macam jejaring sosial menjadi sebuah media komunikasi yang tak kalah penting keberadaannya, Seperti yang diungkapkan oleh Silvi Titasari dari Gresik, mengatakan,

bahwa: Saya browsing di Internet untuk mencari referensi tempat wisata yang bagus untuk adik saya.

Media sosial merupakan suatu bagian yang penting dari sebuah proses pemasaran dan branding dimana setiap bisnis harus memasukkannya sebagai bagian dari strategi mereka secara keseluruhan, seperti yang di ungkapkan oleh Zulhanif Putri dari Tuban, yang mengatakan demikian,

Bahwa: Karena saya melihat di media sosial ada teman saya yang yang berfoto di wisata ini.

Bukan tidak mungkin bahwa media sosial pada era sekarang lebih banyak digunakan sebagai media untuk promosi, seperti Instagram, Facebook dan lain sebagainya, seperti yang di ungkapkan oleh Rendra dari tuban yang mengatakan sebagai berikut,

Yaitu: Saya membuka instagram tidak sengaja saya menemukan akun wisata Indonesian Islamic Art Museum ini

Kerjasama yang dibangun dengan baik tentunya menghasilkan sebuah kesepakatan yang saling menguntungkan dalam menjalankan bisnis, salah satunya kerjasama antara Wisata Bahari Lamongan dan juga Indonesian Islamic Art Museum, sebagaimana yang diungkapkan oleh, Yudistira dari Sidoarjo, mengatakan, bahwa: kebetulan tadi ketika saya ke Wisata Bahari Lamongan, saya diberitahu oleh teman saya yang tadi juga barusan dari sini.

Sebagai salah satu upaya untuk meningkatkan minat kunjungan wisatawan tentunya dengan melakukan berbagai macam inovasi, termasuk menjalin hubungan baik dengan masyarakat sekitar, 
sebagaimana yang sudah diungkapkan oleh Arif dari Lamongan yang mengatakan,

Bahwa: Tidak sengaja bertemu dengan teman yang menjual cinderamata di sini kemudian saya mampir.

Dari wawancara pengunjung yang telah peneliti lakukan menyatakan bahwa mayoritas pengunjung mengetahui informasi tentang wisata Indonesia Islamic Art Museum melalui face to face, kemudian dari media sosial terutama Instagram, kemudian melalui baliho yang ada di depan jalan tempat wisata. Namun yang paling banyak menurut pengunjung adalah melalui face to face, yang terjadi secara tidak disengaja.

\section{Kesimpulan dan Saran}

\section{Kesimpulan}

Dari proses pemaparan data yang dimuat dalam pembahasan, diperoleh kesimpulan tentang proses strategi komunikasi pemasaran Dinas Pariwisata dan Kebudayaan Kabupaten Lamongan dalam mengembangkan pariwisata Indonesian Islamic Art Museum, kesimpulan tersebut diantaranya:

1). Strategi Komunikasi Pemasaran

Dinas Pariwisata dan Kebudayaan

Adapun Tahapan Disparbud dalam strategi komunikasi pemasaran adalah: a). Berkomunikasi dengan pihak pengelola dalam menjalin relasi dengan mengundang sekolah-sekolah, dalam pelaksanaannya adalah menyebar undangan kepada sekolah-sekolah, dan ketika berada di dalam wisata akan dibuat kegiatan, seperti lomba menggambar, mewarnai, dll.

b). Melakukan promosi lewat media sosial, seperti facebook, instagram, kemudian melalui aplikasi yang berbasis android yaitu Lamongan Tourism, dan juga memasukkan pilihan tiket di paket Wisata Bahari Lamongan sehingga lebih mudah mengenalkan wisata ini.

c). Dalam skala formal mengikuti event Mojopahit Travel Fair yang dilaksanakan di Grand City Surabaya. Dalam event tersebut Indonesian Islamic Art Museum mendapatkan juara mini booth terbaik dan pelayanan terbaik.

d). Dalam skala non formal melalui face to face Setiap bertemu dengan teman, tetangga, dan juga saudara adalah bagian dari promosi yang telah dilakukan. Mungkin saat ini baru sebatas itu yang bisa dilakukan oleh Dinas Pariwisata dan Kebudayaan Kabupaten Lamongan.

2). Kendala yang dialami Dinas Pariwisata dan Kebudayaan 
a). Alokasi anggaran dana yang memiliki inovasi-inovasi perencanaan diberikan oleh Pememerintah Daerah dalam penggunaan media apa sebagai masih belum maksimal.

b). Kurangnya Sumber Daya Manusia (SDM) dalam bidang Teknologi Informasi (TI).

c). Pariwisata Indonesian Islamic Art Museum dikelola oleh pihak Swasta.

d). Komunikasi yang dibangun dalam Internal Disparbud belum maksimal.

3). Tanggapan pengunjung terhadap wisata Indonesian Islamic Art Museum.

a). Wisata Indonesian Islamic Art Museum memiliki sarana dan prasarana yang baik dan memadai kemudian ditunjang dengan teknologi yang berbasis Android.

b). Mayoritas pengunjung mengetahui informasi tentang wisata Indonesia Islamic Art Museum melalui face to face, kemudian dari media sosial terutama Instagram, kemudian melalui baliho yang ada di depan jalan tempat wisata.

\section{Saran}

Berdasarkan kesimpulan penelitian, maka penulis merekomendasikan berupa saran-saran sebagai berikut:

1). Untuk meningkatkan efisiensi Dinas Pariwisata dan Kebudayaan dalam melakukan kegiatan strategi komunikasi pemasaran hendaknya disesuaikan berdasarkan tuntutan kebutuhan, sehingga sarana promosi yang lebih tepat dalam proses komunikasi pemasaran, sehingga bisa tepat sasaran sesuai dengan yang diharapkan.

2). Dalam menjalankan suatu organisasi hendaknya kerja sama tim sangat diperlukan dalam segala kegiatan, lebih menyadari bahwa kepentingan organisasi lebih diutamakan daripada kepentingan pribadi agar tercipta kepuasan kerja, kerjasama tim (teamwork), sehingga dapat mencapai visi- misi organisasi yang efisiensi, efektif dan kearah yang lebih baik.Karena hubungan kerja yang kurang baik dapat menghambat segala bentuk kegiatan.

3). Penelitian ini masih belum komprehensif, maka diharapkan bagi penelitian berikutnya yang berminat meneliti dalam bidang strategi komunikasi pemasaran dapat menggunakan pendekatan output, yaitu mengukur produk barang atau jasa yang dihasilkan oleh Dinas Pariwisata dan Kebudayaan berdasarkan tingkat kepuasan masyarakat/wisatawan terhadap pariwisata yang ada di Kabupaten Lamongan. 


\section{Daftar Pustaka}

Abdurrahman, Oemi. 2001. Dasar-Dasar

Public Relations. Bandung: PT. Citra Aditya Bakti

Ardianto, Soemirat Soleh. 2010. Dasar -

Dasar Public Relation. PT. Remaja Rosdakarya. Bandung.

Deddy Mulyana, 2005, Ilmu Komunikasi:

Suatu Pengantar, Bandung, Remaja Rosdakarya.

Effendy, Onong Uchjana. 2008. Dinamika

Komunikasi.Bandung : PT. Remaja Rosdakarya

,Onong Uchjana. 2011. Ilmu Komunikasi:

Teori dan Praktek.Bandung : PT. Remaja Rosdakarya.

Haerah, Kahar. 2015. Materi kuliah ;

Metodologi Penelitian Sosial.

Universitas Muhammadiyah Jember.

Moleong, L. 2012. Metodologi Penelitian

Kualitatif. Bandung: PT Remaja Rosdakarya.

Moriarty, Sandra. 2011. Adverising. Jakarta: Kencana.

Mulyana, Deddy. 2010. Metodologi

Penelitian Kualitatif, Bandung: PT

Remaja Rosdakarya.

Sendjaja, S. Djuarsa. 1994. Teori

Komunikasi. Jakarta: Universitas Terbuka.
Soekadijo, R.G. 1997. Anatomi

Pariwisata. Jakarta. PT Gramedia Pustaka Utama.

Tjiptono, Fandy 2002. Strategi Pemasaran.

Yogyakarta: Andi.

Yoeti, Oka A. 1985. Pemasaran Pariwisata. Bandung: Angkasa.

Yulianita, Neni. 2001. Komunikasi

Pemasaran. Surabaya: Program

Pascasarjana Universitas Dr.

Soetomo.

Fadhlulloh, Muhammad H. 2014. Strategi

Dinas Kebudayan Dan Pariwisata

Kabupaten Banyuwangi Untuk

Promosi Pariwisata Dalam Perspektif

Komunikasi Pemasaran. Skripsi Ilmu

Komunikasi. Surabaya: Universitas

Islam Negeri Sunan Ampel Surabaya. https://suaralamongan.wordpress.com/pro

fil-lamongan(diakses pada tanggal 12

Desember 2017)

https://id.wikipedia.org/wiki/Kabupaten

Lamongan(diakses pada tanggal 12

Desember 2017)

http://catatankomunikasi.blogspot.co.id/2

013/07/4-tahapan-dalam-proses-

public-relations.html (diakses pada

tanggal 22 Maret 2018)

https://travelingyuk.com/indonesian-

islamic-art-museum/95930/ (diakses

pada tanggal 11 April 2018) 
https://www.kompasiana.com/faridatoma/ indonesian-islamic-art-museumreligi-paling-keren-dinusantara_58d36d14b07a61260cf306 3f ( diakses pada tanggal 14 April 2018)
https://id.wikipedia.org/wiki/Kabupaten Lamongan (diakses pada tanggal 14 April 2018) 